Eur J Clin Chem Clin Biochem

1995; 33:763-774

(C) 1995 Walter de Gruyter \& Co.

Berlin · New York

\title{
Nitric Oxide Regulates Peroxisomal Enzyme Activities ${ }^{1}$ )
}

\author{
By Karl Kremser ${ }^{1}$, Herbert Stangl ${ }^{1}$, Kalipada Pahan ${ }^{2}$ and Inderjit Singh ${ }^{2}$ \\ 1 Institut für Medizinische Chemie, Universität Wien, Wien, Austria \\ 2 Division of Developmental Neurogenetics, Department of Pediatrics, Medical University of South Carolina, \\ Charleston, SC, USA
}

(Received May 22/August 14, 1995)

Dedicated to Professor Dr. Erich Kaiser on the occasion of his 70th birthday

Summary: We have previously shown that peroxisomes are involved in the production and detoxification of reactive oxygen species and that peroxisomal functions are damaged by such oxygen species. Since nitric oxide is not only a cellular messenger, but also a free radical, it would be interesting to detect a connection between nitric oxide levels and peroxisomal enzyme activities. To determine if nitric oxide has an effect on the activities of peroxisomal functions and whether this effect is based solely on its chemical properties as reactive oxygen species or its action as a second messenger, effectors of the cellular nitric oxide level were applied to a cell model (human skin fibroblasts in culture) or directly to the enzymatic assays or both. If applied to the monolayer at non-cytotoxic concentrations, $\mathrm{N}$-nitro- $L$-arginine methyl ester hydrochloride, an inhibitor of nitric oxide synthase (EC 1.14.13.39), increased catalase (EC 1.11.1.6) activity by more than $10 \%$ and decreased the activity of the peroxisomal fatty acid oxidation system by more than $10 \%$. The effect was concentration-dependent. $L$-Arginine had the contrary effect. Combinations of $L$-arginine and $N$-nitro- $L$-arginine methyl ester hydrochloride compensated one another. If applied directly to the assays, S-nitroso-N-acetylpenicillamine and sodium nitroprusside inhibited catalase activity in a concentration-dependent manner. Sodium nitroprusside had no effect on the peroxisomal $\beta$-oxidation system unless cells were pretreated with $\mathrm{N}$-nitro- $L$ arginine methyl ester overnight (50\% inhibition).

The results show a differential effect for the application of nitric oxide-effectors on fibroblast monolayers, cell suspensions and under assay conditions. Depending on the conditions of the incubation, nitric oxide applied to the cell monolayer at low doses acts as a second messenger in cells rather than as reactive oxygen species. Under assay conditions the effect of nitric oxide is more likely that of a reactive oxygen species because it inhibits all measured enzyme activities.

\section{Introduction}

Peroxisomes were first described in 1954 by Rhodin (1). Since their discovery peroxisomes have been found to be present in all mammalian cells except mature red

\footnotetext{
1) This work was supported by a grant from the National Institute of Health to I.S. (N.I.H. 22576) and K. K. was supported by a grant-in-aid from the University of Vienna, Austria.
}

blood cells $(2,3)$; however their size, number and functions may vary in different tissues $(3,4)$. The importance of peroxisomes is underlined by the discovery of a number of diseases caused by dysfunction of peroxisomal metabolic pathways (5). Originally peroxisomes were described to contain a primitive respiratory chain in which electrons removed from various metabolites reduce oxygen to $\mathrm{H}_{2} \mathrm{O}_{2}$, which is then reduced to $\mathrm{H}_{2} \mathrm{O}$ by 
catalase $^{2}$ ) (3). The discovery of enzymes of the glyoxylate pathway (6), fatty acid oxidation $(6,7)$, especially very long chain fatty acids (8) and enzymes for the synthesis of precursors of plasmalogens $(9,10)$ underscores the importance of this organelle in cellular metabolism. In the last 25 years more than 60 enzymes have been shown to be present in peroxisomes (3). One of the important functions of peroxisomes is the metabolism of reactive oxygen species. The reactive oxygen species $\left(\mathrm{O}_{2}^{-}, \mathrm{OH}^{\bullet}, \mathrm{H}_{2} \mathrm{O}_{2}\right)$ are normal by-products of cellular metabolism $(11,13)$ and levels of these reactive oxygen species are kept in check by metabolism by the antioxidant enzymes (12). The oxygen consumed in peroxisomes is converted to $\mathrm{H}_{2} \mathrm{O}_{2}$ and superoxide $\left(\mathrm{O}_{2}^{-}\right)$, as suggested by the presence of $\mathrm{H}_{2} \mathrm{O}_{2}$ and $\mathrm{O}_{2}^{-}$producing enzymes. An imbalance in activities in the synthesis and degradation in ischaemia-reperfusion $(14,15,16)$ and in animals treated with sublethal doses of lipopolysaccharide (17) and peroxisomal proliferators $(18,19)$ are known to cause oxidative stress in peroxisomes. Recently several authors have investigated the damaging effect of reactive oxygen species with respect to peroxisomal functions $(20,21)$. Both catalase and the oxidation of very long chain fatty acids were shown to be inhibited by reactive oxygen species $(20,21)$.

Nitric oxide is a short lived inorganic free radical gas of the formula ${ }^{\bullet} \mathrm{N}=\mathrm{O}$. In mammalian cells it is produced from $L$-arginine by oxidation of a guanidino nitrogen by nitric oxide synthase ${ }^{2}$ ) yielding $L$-citrulline as a co-product (22-25). In mammalian cells nitric oxide synthase exists in 3 isoforms (24) and is active in its homodimeric form. Two of the isoforms are generally constitutive and their activity depends on elevated levels of $\mathrm{Ca}^{2+}$. The third isoform is inducible and the activity is generally independent of elevated levels of $\mathrm{Ca}^{2+}$. Nitric oxide has numerous functions, mediating physiological processes in many organs such as neuroprotection (26) by regulating various enzyme activities $(24,27,28)$ and during pathophysiological conditions by its cytotoxic effects $(26-32)$. The effects of nitric oxide are mediated by peroxynitrite, produced by the reaction of nitric oxide with $\mathrm{O}_{2}^{-}(29,30)$. Nitric oxide affects the DNA synthesis in cultured human skin fibroblasts (33). Fibroblasts contain inducible nitric oxide synthase and produce nitric oxide $(22,23,34,35)$. Both the presence of nitric oxide synthase and the described effects of nitric oxide in fibroblasts make it an interesting model system for investigations of regulatory effects of nitric oxide on cellular and organelle level.

\footnotetext{
2) Enzymes:

Catalase, hydrogen peroxide : hydrogen-peroxide oxidoreductase (EC 1.11.1.6)

Nitric oxide synthase, $L$-arginine, NADPH : oxygen oxidoreductase (nitric oxide forming) (EC 1.14.13.39)
}

We examined the effect of compounds that inhibit the synthesis of nitric oxide or produce nitric oxide on the peroxisomal function of human skin fibroblasts and describe for the first time that peroxisomal enzyme activities are regulated by nitric oxide.

$\cdot 1$

\section{Materials and Methods}

\section{Cell lines (fibroblasts) and tissue culture conditions}

Control fibroblast cell lines were derived from healthy subjects. All cells were used in passages 10-16. Fibroblasts were grown in Dulbecco's Modified Eagle medium (Gibco/BRL; Paisley, UK) supplemented with $150 \mathrm{ml} / \mathrm{i}$ bovine calf serum (Gibco/BRL; Paisley, UK) and gentamycin $(50 \mathrm{mg} / \mathrm{l})$ under isobaric conditions $(5 \%$ $\mathrm{CO}_{2}$, air). Cells were harvested by trypsinisation.

\section{Protein assay}

Protein was estimated by the method of Bradford using bovine serum albumin as a standard (36).

\section{Catalase assay}

Catalase enzyme activity was measured as described previously $(37,38)$.

\section{Oxidation of $\left[1-{ }^{14} D\right]$ phytanic acid}

Assays were performed on cell suspensions of trypsinized, unbroken fibroblasts from control cell lines under isotonic conditions. The oxidation of phytanic acid to pristanic acid was determined as $\left[{ }^{14} \mathrm{C}\right] \mathrm{O}_{2}$ release from $1-\left[{ }^{14} \mathrm{C}\right]$ phytanic acid. The reaction was initiated with $100-200 \mu \mathrm{g}$ protein (fibroblast suspension) and stopped with $\mathrm{H}_{2} \mathrm{SO}_{4}(4 \mathrm{~mol} / \mathrm{l})$. The $\left[{ }^{14} \mathrm{C}\right] \mathrm{CO}_{2}$ was collection in $\mathrm{KOH}$-wetted cotton by shaking the reaction tubes overnight $(39,40)$.

\section{Oxidation of $\left[1-{ }^{14} \mathrm{C}\right]$ lignoceric acid}

Assays were performed on cell suspensions of trypsinized, unbroken fibroblasts from control cell lines under isotonic conditions. $\left[1-{ }^{14} \mathrm{C}\right]$ Lignoceric acid $(2 \mathrm{GBq} / \mathrm{mol}, 0.403 \mathrm{MBq})$ was suspended in $4 \mathrm{ml}$ of a solution of $\alpha$-cyclodextrin $(20 \mathrm{~g} / \mathrm{l})$ in isotonic buffer $(0.25$ $\mathrm{mol} / \mathrm{l}$ sucrose, $3 \mathrm{mmol} / \mathrm{imidazole}, \mathrm{pH}=7.2,1 \mathrm{mmol} / \mathrm{EDTA}$, $1 \mathrm{ml} / \mathrm{l}$ ethanol) by sonication. The reaction was initiated by the addition of $\left[1-{ }^{14} \mathrm{C}\right]$ lignoceric acid $(2.52 \mathrm{kBq})$ to fibroblasts $(100-$ $150 \mu \mathrm{g}$ protein) suspended in $200 \mu \mathrm{l}$ isotonic buffer. The tubes were incubated for 30 minutes or $1 \mathrm{~h}$ at $37^{\circ} \mathrm{C}$ in a shaking waterbath. The reaction was stopped by the addition of $\mathrm{KOH}$ in methanol followed by incubation at $60^{\circ} \mathrm{C}$ in a shaking waterbath. The amount of radioactivity in the upper phase of the Folch partition represents the rate of oxidation of lignoceric acid $(8,38)$.

\section{Treatment with effectors}

Direct nitric oxide application was performed with S-nitroso-Nacetylpenicillamine, a nitric oxide producing compound (41), which was dissolved in ethanol. This solution was added to fibroblast monolayers, cell suspensions or assays to give the concentrations indicated. N-Nitro- $L$-arginine methyl ester hydrochloride (Biomol; Hamburg, Germany), $L$-arginine, $D$-arginine and sodium nitroprusside (sodium pentacyanonitrosylferțate(III), Sodium Nitroferricyanide, SIGMA, Vienna, Austria) were prepared as stock solutions in fresh Hank's balanced salt solution (Gibco/BRL; Paisley, UK) immediately before application to assays, cell monolayers or suspensions to yield the concentrations indicated.

The following types of application of effectors were performed: 


\section{Treatment I}

The effectors were $N$-nitro- $L$-arginine methyl ester $(1 \mathrm{mmol} / \mathrm{h}), L$ arginine and $D$-arginine $(10 \mathrm{mmol} / \mathrm{l})$. The concentrations are final concentrations in tissue culture media. A single dose was applied to fibroblast monolayers 20 hours before performing the assays (activity of catalase and oxidation of lignoceric acid, fig. $1 a$ and $b$ ).

\section{Treatment 2}

Test of the concentration dependence under tissue culture conditions

The effectors used (given concentrations are those in tissue culture media) were $N$-nitro- $L$-arginine methyl ester $(1,2,5$ and $7 \mathrm{mmol} / 1)$, $L$-arginine $(10 \mathrm{mmol} / \mathrm{h}, 20 \mathrm{mmol} / \mathrm{l})$ and combinations of $\mathrm{N}$-nitro- $L$ arginine methyl ester and $L$-arginine $(1 \mathrm{mmol} / 1 \mathrm{~N}$-nitro- $L$-arginine methyl ester $/ 10 \mathrm{mmol} / / L$-arginine and $2 \mathrm{mmol} / / \mathrm{N}$-nitro- $L$-arginine methyl ester $/ 20 \mathrm{mmol} / / L$-arginine). A single dose was applied to monolayers 20 hours before performing the assays (activity of catalase, oxidation of lignoceric acid and phytanic acid, fig. $2 a, b, c)$.

\section{Treatment 3}

Pretreatment ( 24 hours) of cell monolayers was performed with 20 mmol/l $L$-arginine (fig. $3 \mathrm{c}, \mathrm{f}$ ) or $2 \mathrm{mmol} / 1 \mathrm{~N}$-nitro- $L$-arginine methyl ester (fig. 3b,e) followed by the addition of effectors to the assays (S-nitroso-N-acetylpenicillamine, ethanol as control for the addition of S-nitroso-N-acetylpenicillamine, sodium nitroprusside, $\mathrm{N}$-nitro- $L$-arginine methyl ester, all $2 \mathrm{mmol} / 1$ and $20 \mathrm{mmol} / \mathrm{L} L$-arginine) to distinguish between the effect of nitric oxide on enzymes in intact cells and enzyme systems under assay conditions (fig. $3 a-f)$.

\section{Treatment 4}

Concentration dependence of catalase-inhibition by nitric oxide

Stock solutions of S-nitrose-N-acetylpenicillamine in ethanol and sodium nitroprusside in fresh Hank's balanced salt solution were applied directly to the assays to give concentrations ranging from $0.02 \mathrm{mmol} / \mathrm{l}$ to $2 \mathrm{mmol} / \mathrm{l}$ (fig. $4 \mathrm{a}$ and $\mathrm{b}$ ).

\section{Treatment 5}

Direct application of nitric oxide-donor stock solutions or ethanol (to give $2 \mathrm{mmol} / \mathrm{l}$ sodium nitroprusside, $2 \mathrm{mmol} / \mathrm{l} \mathrm{S}$-nitroso- $\mathrm{N}$-acetylpenicillamine or ethanol blank) to monolayers and suspended intact cells. Monolayers were incubated with effectors for 16 hours (fig. 5a and b, 16 hours) and untreated cells suspended in complete tissue culture media were incubated with effectors for 1 hour (fig. $5 a$ and $b, 1$ hour) in a shaking waterbath $\left(37^{\circ} \mathrm{C}\right)$ to distinguish between short term and long term effect of nitric oxide on whole cells. Cells were washed twice with fresh Hank's balanced salt solution to remove the effectors before assays (fig. $5 a$ and $b$ ).

\section{Statistics}

Statistical comparisons were made using the analysis of variance followed by Student's t-test; $n=6$, unless other values are given. The expression 'significant' is used for $\mathrm{p}<0.05$.

\section{Results and Discussion}

\section{Treatment 1}

(inhibition and activation of the synthesis of nitric oxide)

The first step in determining whether a cellular process depends on nitric oxide or nitric oxide synthase activity is to apply specific inhibitors of nitric oxide synthase to decrease the intracellular nitric oxide level. N-Nitro- $L$ arginine methyl ester, one of the best known inhibitors of nitric oxide synthase (23), was used to reduce the cellular nitric oxide synthesis rate. $L$-Arginine was applied to induce cellular nitric oxide synthesis, thus elevating the intracellular nitric oxide level. $D$-Arginine served as a blank for $L$-arginine because it is not converted to nitric oxide by nitric oxide synthase and thus has no effect on the synthesis rate and intracellular level of nitric oxide (fig. 1 and 2). N-Nitro- $L$-arginine methyl ester was applied at a concentration of $1 \mathrm{mmol} / \mathrm{l}$. The concentrations of $L$-arginine and $D$-arginine, respectively, alone or in combination with $N$-nitro- $L$-arginine methyl ester were $10 \mathrm{mmol} / \mathrm{l}$. N-Nitro- $L$-arginine methyl ester, $L$-arginine and $D$-arginine were added to monolayers 20 hours before harvesting the cells (fig. 1a and $b$ ). The rate of the oxidation of lignoceric acid was determined in cell suspension as described in the methods section. Following the treatment of fibroblast monolayers with the nitric oxide synthase inhibitor N-nitro- $L$ arginine methyl ester, catalase activity is more than $10 \%$ higher than control values $(n=6, p<0.01)$, (fig. $1 a)$. $D$-Arginine has no effect, as expected, since it is not a suitable substrate for nitric oxide synthase and $L$-arginine inhibits catalase activity and compensates the effect of N-nitro- $L$-arginine methyl ester (fig. $1 \mathrm{a}$ ). The oxidation of lignoceric acid is significantly affected by both $\mathrm{N}$-nitro- $L$-arginine methyl ester $(\mathrm{n}=5, \mathrm{p}<0.05)$ and $L$ arginine $(n=5, p<0.05)$. Effector doses, which enhance catalase activity, decrease lignoceric acid oxidation activity and vice versa (fig. 1b). Under tissue culture conditions catalase and the very long chain fatty acid oxidation system (peroxisomal $\beta$-oxidation system) are affected by nitric oxide in an opposite way, probably due to differential regulation of these enzyme systems by nitric oxide or peroxynitrite.

\section{Treatment 2}

\section{(concentration dependence of effects under cell culture conditions)}

To examine the concentration dependence of $N$-nitro- $L$ arginine methyl ester and/or $L$-arginine, different concentrations of the effectors $N$-nitro- $L$-arginine methyl ester, $L$-arginine or both were added to the cells in culture (fig. $2 a-c$ ). The increase of the activity of catalase is still significant $(\mathrm{n}=6, \mathrm{p}<0.01$ for $1 \mathrm{mmol} / \mathrm{l}$ and $2 \mathrm{mmol} / 1 \mathrm{~N}$-nitro- $L$-arginine methyl ester), but does not fully follow the concentration profile of $\mathrm{N}$-nitro- $L$-arginine methyl ester (fig. 2a). At higher concentrations of $\mathrm{N}$-nitro- $L$-arginine methyl ester $(5$ and $7 \mathrm{mmol} / \mathrm{l})$ the elevation of catalase activity becomes insignificant. On the other hand, both $L$-arginine and combinations of $\mathrm{N}$ nitro- $L$-arginine methyl ester and $L$-arginine at both concentrations decrease catalase activity (fig. 2a). The decrease caused by $20 \mathrm{mmol} / \mathrm{l} L$-arginine is more pro- 
nounced that that of $10 \mathrm{mmol} / 1 \mathrm{~L}$-arginine which reflects the concentration dependence.

The inhibition of the oxidation of lignoceric acid (fig. 2b) and phytanic acid (fig. 2c) by N-nitro- $L$-arginine methyl ester is concentration-dependent (contrary to the activation of catalase activity), so that the lower the concentration of nitric oxide, the lower the activity of the oxidation of lignoceric and phytanic acids. Combined application of $1 \mathrm{mmol} / 1 \mathrm{~N}$-nitro- $L$-arginine methyl ester and $10 \mathrm{mmol} / 1 \mathrm{~L}$-arginine strongly inhibits (as is the case for the activity of catalase as shown in fig. 2a) instead of compensating the effects. Combined with $2 \mathrm{mmol} / \mathrm{l}$ $\mathrm{N}$-nitro- $L$-arginine methyl ester, $20 \mathrm{mmol} / \mathrm{l} L$-arginine has almost no effect. $L$-Arginine $(10 \mathrm{mmol} / \mathrm{l})$ stimulates both the activity of the oxidation of lignoceric and phytanic acids. $L$-Arginine $(20 \mathrm{mmol} / \mathrm{l})$ gives the same result as in combination with $2 \mathrm{mmol} / 1 \mathrm{~N}$-nitro- $L$-arginine methyl ester. Application of the nitric oxide synthaseinhibitor N-nitro- $L$-arginine methyl ester has an influence on the activity of peroxisomal enzyme systems: Catalase activity is enhanced, the oxidations of very long chain fatty acids and phytanic acid are inhibited. The effects are mainly concentration dependent. $L$-Arginine decreases catalase activity and increases the activity of the peroxisomal $\alpha$ - and $\beta$-oxidation systems.

\section{Treatment 3}

(combination of overnight treatment and addition of effectors to the assays)

This set of incubations (fig. 3) was similar to the above mentioned experiments except for the following differences: Cell monolayers of human skin fibroblasts were incubated with $\mathrm{N}$-nitro- $L$-arginine methyl ester or $L$-ar-
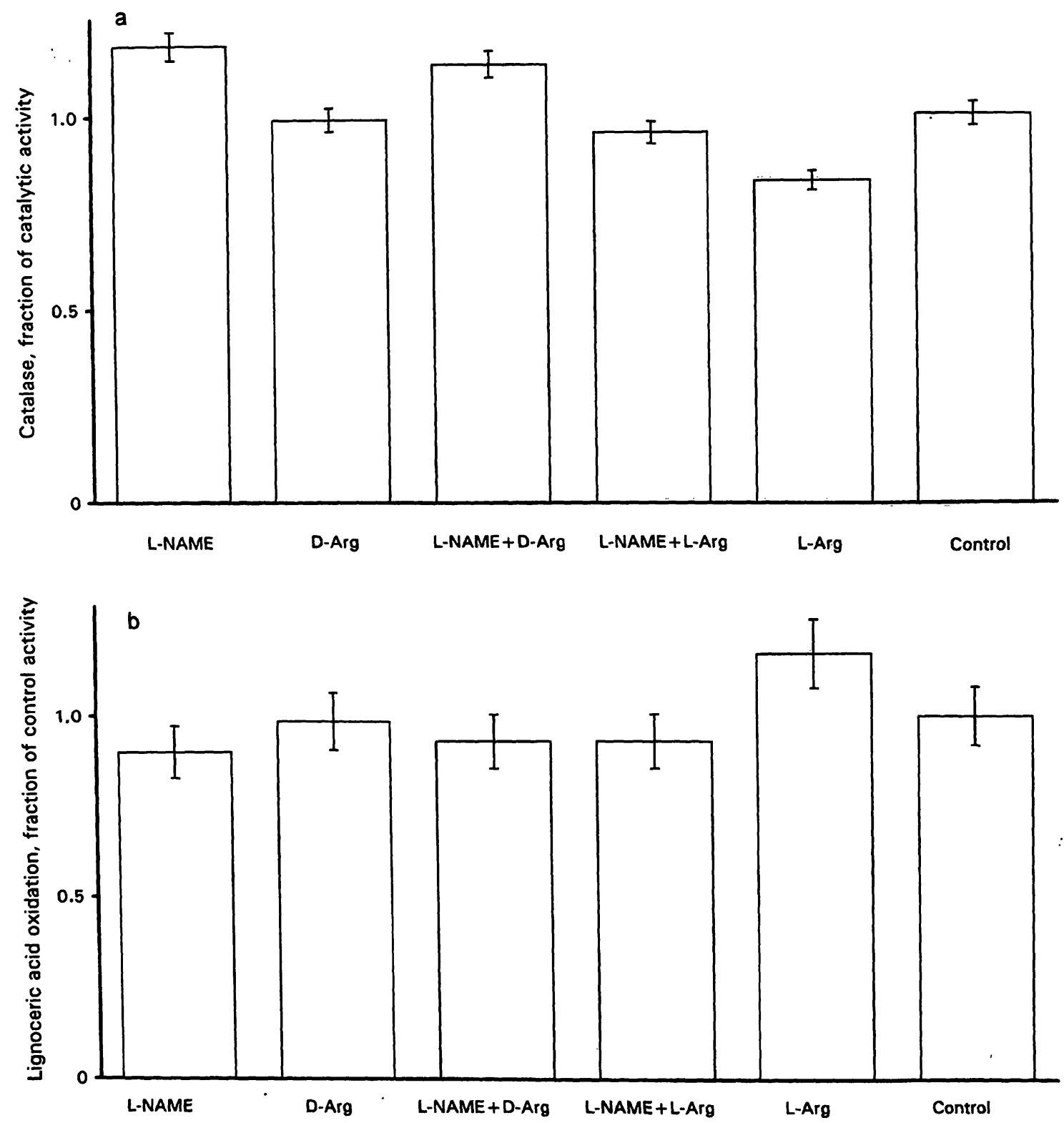

Fig. 1 Treatment 1: Activity of catalase (a) and oxidation of lignoceric acid (b) after 20 hours of incubation of cell monolayers

with $\mathrm{N}$-nitro- $L$-arginine methyl ester (L-NAME, $1 \mathrm{mmol} / \mathrm{l}$ ), $L$-arginine (L-arg, $10 \mathrm{mmol} / \mathrm{l})$ and $D$-arginine (D-arg, $10 \mathrm{mmol} / \mathrm{l}$ ). 
ginine for 24 hours (= pre-treatment) at higher concentrations than in treatment $1(2 \mathrm{mmol} / \mathrm{l}$ and $20 \mathrm{mmol} / \mathrm{l}$, respectively). Cells (pre-treated cells and untreated con- trols) were then harvested according to the procedure described in the methods section (low centrifugal force, no sucrose or imidazole, suspension of cells in Hank's
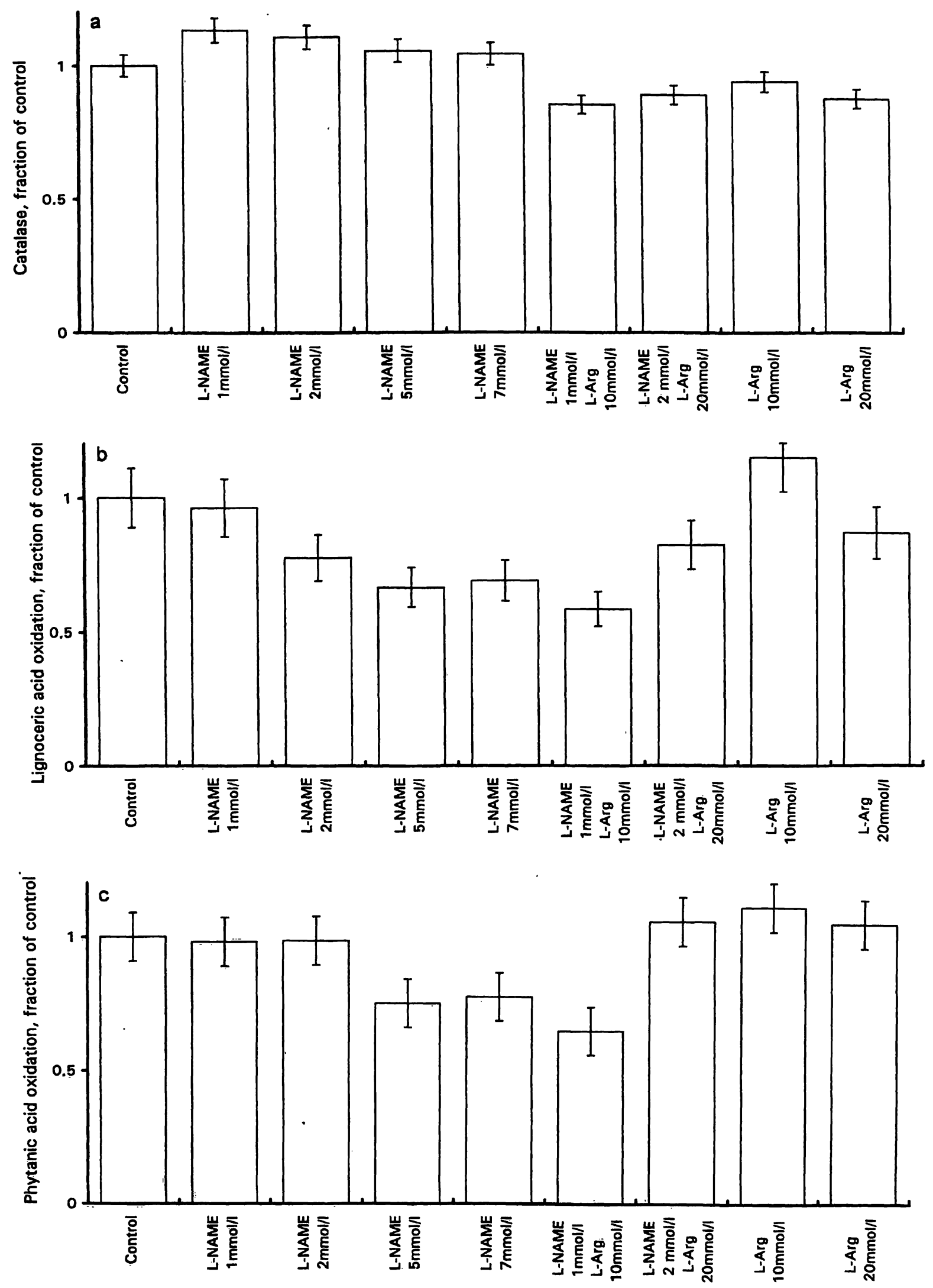

Fig. 2 Treatment 2: Activities of catalase (a), oxidation of lignoceric acid (b) and phytanic acid (c) after incubation of cell monolayers for 20 hours with a single dose of $N$-nitro- $L$-arginine methyl ester (L-NAME, 1, 2, 5 and $7 \mathrm{mmol} / 1$ ), $L$-arginine (L-arg, 10 $\mathrm{mmol} / \mathrm{l}$ and $20 \mathrm{mmol} / \mathrm{l}$ ) and combinations of $\mathrm{N}$-nitro- $L$-arginine methyl ester and $L$-arginine (L-NAME, $1 \mathrm{mmol} / / \mathrm{L}$-arg, $10 \mathrm{mmol} / 1$ and L-NAME, $2 \mathrm{mmol} / \mathrm{l} / \mathrm{L}$-arg, $20 \mathrm{mmol} / \mathrm{l})$. 

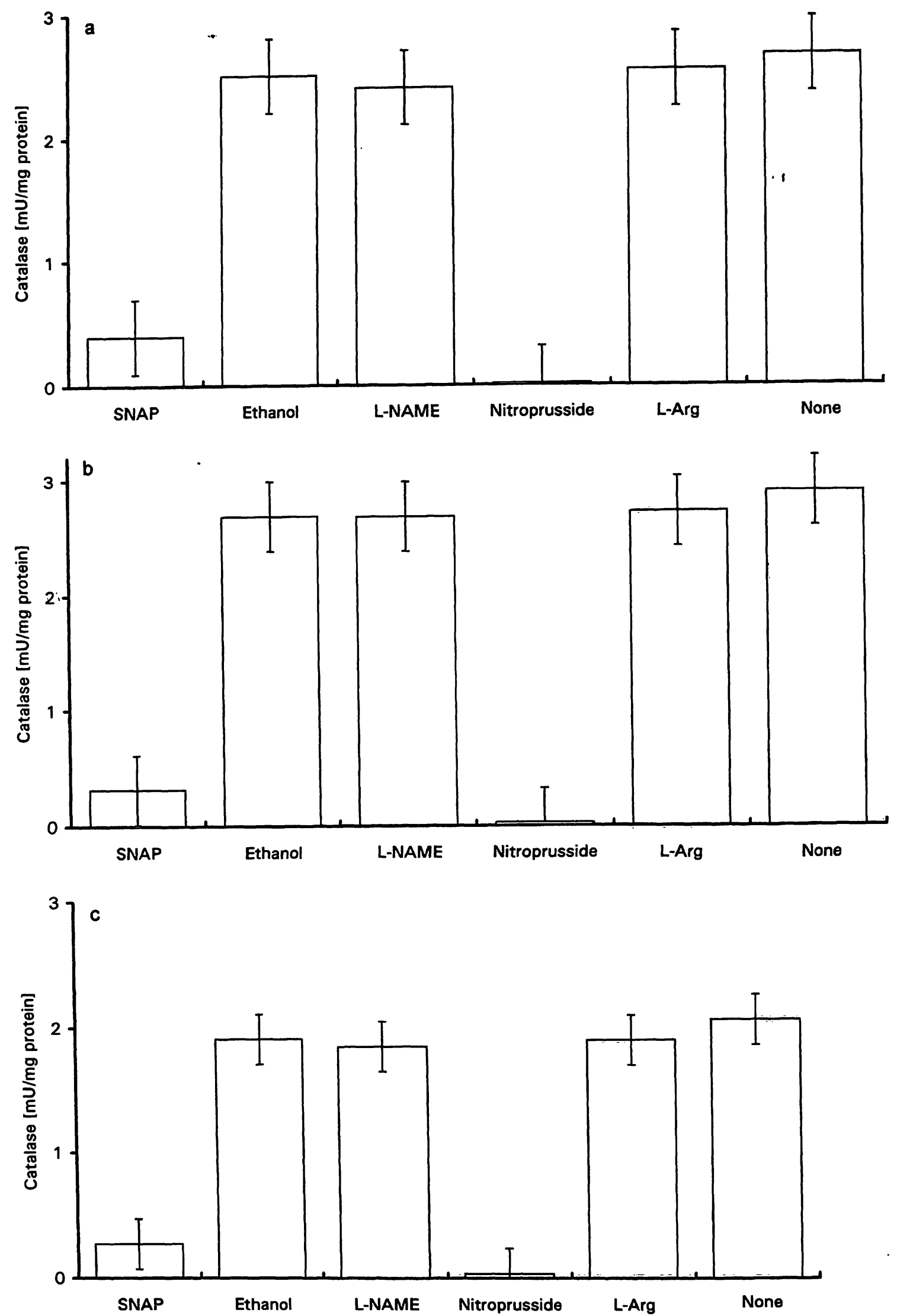

Fig. 3 Treatment 3: Pre-treatment of cell monolayers for 24 hours with $L$-arginine (c and $\mathrm{f}, \mathrm{L}$-arg, $20 \mathrm{mmol} / \mathrm{l}$ ) or $\mathrm{N}$-nitro- $L$-arginine methyl ester ( $b$ and e, L-NAME, $2 \mathrm{mmol} / \mathrm{l}$ ) followed by the addition of S-nitroso- $\mathrm{N}$-acetylpenicillamine (SNAP, $2 \mathrm{mmol} / \mathrm{l}$ ), ethanol as a control for the addition of S-nitroso- $\mathrm{N}$-acetylpenicillamine, sodium nitroprusside $(2 \mathrm{mmol} / \mathrm{l}), \mathrm{N}$-nitro- $L$-arginine methyl ester (L-NAME, $2 \mathrm{mmol} / \mathrm{l}$ ) and $L$-arginine ( $\mathrm{L}-\arg , 20 \mathrm{mmol} / \mathrm{l}$ ) to the as-

a) Activity of catalase without pre-treatment of monolayers but addition of effectors to the assay.

b) Activity of catalase after pretreatment of the monolayer with $\mathrm{N}$ nitro- $L$-arginine methyl ester (L-NAME) followed by addition of effectors to the assay.

c) Activity of catalase after pretreatment of the monolayer with $L$ says. 

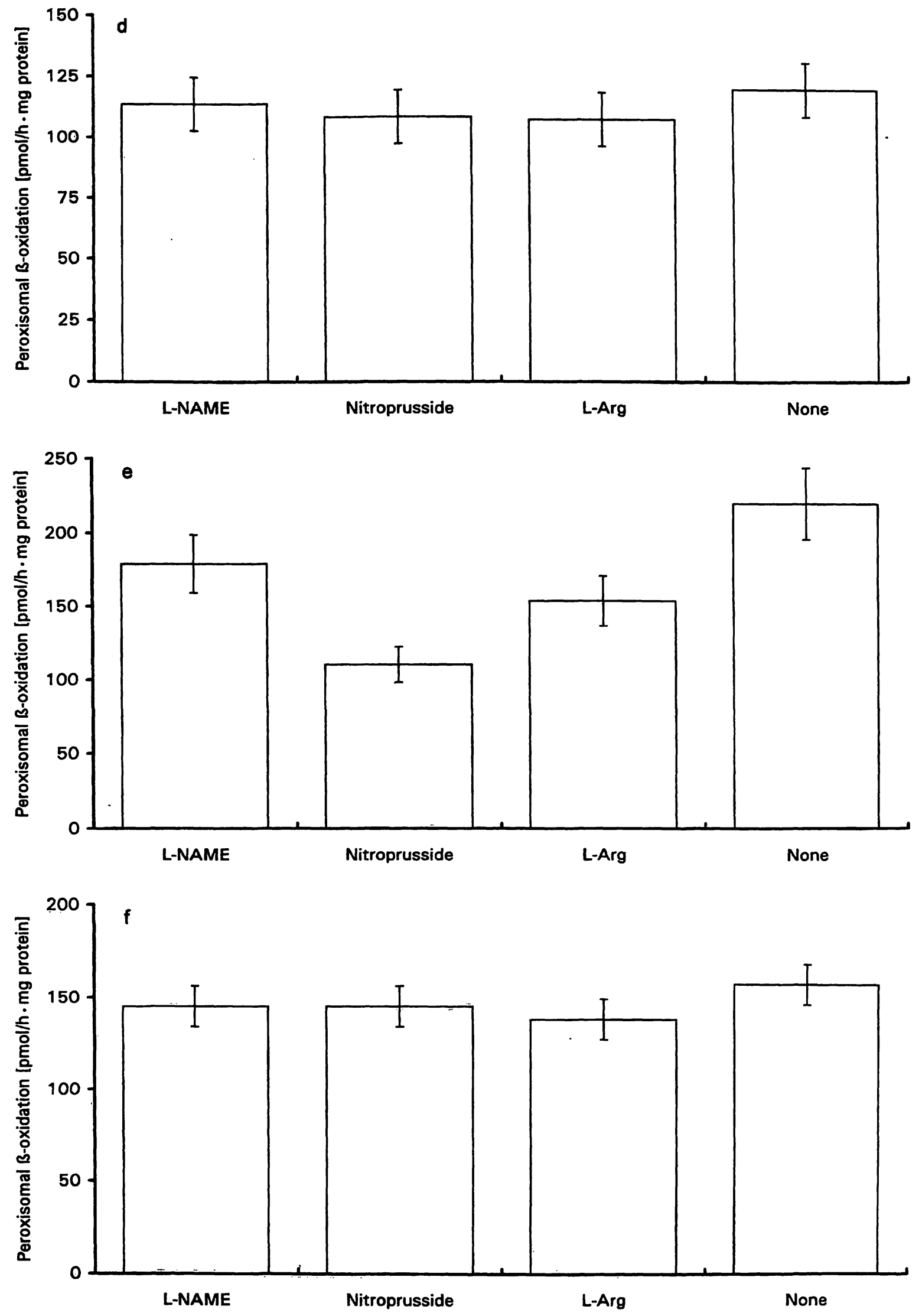

Fig. 3 Continued

d) Activity of the peroxisomal $\beta$-oxidation without pre-treatment of monolayers but addition of effectors to the assay.

e) Activity of the peroxisomal $\beta$-oxidation after pretreatment of the monolayer with $N$-nitro- $L$-arginine methyl ester (L-NAME) followed by addition of effectors to the assay. f) Activity of the peroxisomal $\beta$-oxidation after pretreatment of the monolayer with $L$-arginine ( $\mathrm{L}$-arg) followed by addition of effectors to the assay. 
balanced salt solution) and incubated with effectors under assay conditions. The reaction of lignoceric acid oxidation, performed in suspensions of intact cells, was initiated by changing the temperature from 4 to $37^{\circ} \mathrm{C}$, not by addition of sample to the reaction mixture or substrate to the reaction mixture (see methods). Thus nitric oxide producing substances could be added immediately before the start of the reaction. Likewise, for the catalase assay, samples were not incubated with nitric oxide synthase/nitric oxide modulators prior to the assay. Nitric oxide synthase/nitric oxide modulators were added immediately before the start of the reaction.

Cell monolayers were incubated overnight with $L$-arginine $(20 \mathrm{mmol} / \mathrm{l}$, fig. $3 \mathrm{c}$ and $\mathrm{f})$ or $\mathrm{N}$-nitro- $L$-arginine methyl ester ( $2 \mathrm{mmol} / \mathrm{l}$, fig. $3 \mathrm{~b}$ and e). Cells without pretreatment served as controls for the effect of the incubations performed under assay conditions (fig. $3 a$ and d). Treated and untreated cells were harvested and, under assay conditions for catalase and oxidation of lignoceric acid, incubated with substances influencing nitric oxide metabolism (N-nitro- $L$-arginine methyl ester and $L$-arginine, fig. $3 \mathrm{a}-\mathrm{f}$ ) or nitric oxide producing chemicals (Snitroso- $\mathrm{N}$-acetylpenicillamine and sodium nitroprusside, fig. $3 a-f)$. S-Nitroso-N-acetylpenicillamine and sodium nitroprusside spontaneously release nitric oxide when solubilized. S-Nitroso-N-acetylpenicillamine is not soluble in aqueous solutions, therefore samples (fig. $3 a-f$ ) containing the same volume of ethanol which was used for solubilizing the appropriate amount of S-nitroso-Nacetylpenicillamine were used as controls. Since the oxidation of lignoceric acid is carried out at isotonic conditions with intact suspended cells, S-nitroso-N-acetylpenicillamine could not be used as nitric oxide donor since the high ethanol concentration $(5 \mathrm{ml} / \mathrm{l})$ necessary for its solubilisation makes the determination of the oxidation rate of lignoceric acid impossible under our assay conditions. Sodium nitroprusside also spontaneously releases nitric oxide in solution (aqueous solutions, neutral $\mathrm{pH}$ ) at ambient light. Therefore solutions have to be kept in the dark until the start of the reaction. In figures $3 a-e$ 'None' means no addition of nitric oxide modulators to the assay to show the effect of the pre-treatment for 24 hours with $\mathrm{N}$-nitro- $L$-arginine methyl ester and $L$-arginine. In all three pre-treatments (fig. $3 a-c$ ) the pattern of the activity changes of catalase, as a response to the effectors added under assay conditions, is very similar except for the absolute specific activities which depend on the pre-treatment. In all cases catalase activity is severely inhibited by direct addition of nitric oxide releasing drugs (sodium nitroprusside and S-nitroso-N-acetylpenicillamine) to the assay. Since the reaction temperature for the catalase assays is close to $0^{\circ} \mathrm{C}$, it was expected that $\mathrm{N}$-nitro- $L$-arginine methyl ester (which inhibits nitric oxide synthesis) and $L$-arginine (which has to be converted to citrulline to yield nitric oxide via the nitric oxide synthase pathway) would not show a large effect and their direct effect, if any at all, would be much less pronounced than that of the nitric oxide releasing chemicals (S-nitroso-N-acetylpenicillamine and sodium nitroprusside). Addition of $2 \mathrm{mmol} / \mathrm{l}$ nitroprusside to the assay completely inhibits catalase' áctivity. S-Nitroso-Nacetylpenicillamine at the same concentration has less effect but still significantly inhibits catalase activity. The effect of ethanol is negligible but, due to a very low solubility of S-nitroso- $\mathrm{N}$-acetylpenicillamine under assay conditions, the nitric oxide release of S-nitroso-Nacetylpenicillamine is also decreased.

On addition of effectors under assay conditions the oxidation of lignoceric acid is inhibited in all cases, contrary to the results of the overnight incubation with effectors. This can be explained by the inhibition of catalase by $L$-arginine (fig. $1 \mathrm{a}$ and $2 \mathrm{~b}$ ) and nitroprusside under assay conditions (fig. $3 a-c$ and $4 a$ ), which causes higher levels of hydrogen peroxide in peroxisomes and thus inhibits the oxidation of lignoceric acid (42), which under test conditions by itself produces higher hydrogen peroxide amounts than in cell culture. N-Nitro- $L$-arginine methyl ester inhibits the rate of oxidation of lignoceric acid, both at application to the monolayers (fig. $2 b$ ) and after pre-treatment also under assay conditions (fig. $3 e$ and $f$ ). Incubation with $N$-nitro- $L$-arginine methyl ester for 20 hours results in significantly increased oxidation rates of lignoceric acid $(\mathrm{p}<0.001, \mathrm{n}=5$, fig. $3 \mathrm{e}$ compared to $3 \mathrm{~d}$, none) which can be caused by newly synthesized enzyme protein for the peroxisomal $\beta$-oxidation, probably acyl CoA-oxidase, the rate limiting enzyme for the oxidation of very long chain fatty acids, which after depletion of endogenous very long chain fatty acids causes a virtually higher turnover of labeled exogenous substrate under assay conditions. Thus, contrary to the pre-treatment with $L$-arginine, pre-treatment with $N$-nitro- $L$-arginine methyl ester enhances the effect of modulators applied to the cell suspension assays: Even the inhibiting effect of $N$-nitro- $L$-arginine methyl ester added under assay conditions is significant ( $p<0.05, n=5$, fig. 3e, L-NAME). All agents lower the activity of the oxidation of lignoceric acid (fig. 3e) as is the case after pre-treatment with $L$-arginine (3d and $\mathrm{f})$. Since this significant decrease is only seen after 24 hours pre-treatment with $\mathrm{N}$-nitro- $L$-arginine methyl ester, longer decrease (for 1 day versus 20 hours) of the intracellular nitric oxide level induces the peroxisomal $\beta$-oxidation system. The advantage of our cell suspension assay lies in its close reflection of physiological conditions, because we are operating with a complete and intact suspended cellular system. On the other hand it also reflects the activities of many processes, not only the peroxisomal fatty acid oxidation system, which can 
be activated/inhibited at more than one position. It also monitors the uptake of the fatty acid through the cellular membrane, the intracellular transport of the fatty acid and is influenced by intracellular pools of very long chain fatty acids.

\section{Treatment 4}

(dose dependence of direct catalase inhibition by nitric oxide)

The inhibition of catalase activity by nitric oxide is dose dependent (fig. $4 a$ and $b$, dose response curves for $S-$ nitrose- $\mathrm{N}$-acetylpenicillamine and sodium nitroprusside). The inhibition curves are different. The reason for the difference is the low solubility of S-nitroso-N-acetylpenicillamine in aqueous solutions and the limited decomposition on solubilisation. Concentrations which are without effect if applied to monolayers inhibit more than nine tenths of the catalase activity (see treatment 5,1 hour).

\section{Treatment 5 \\ (comparison of short and long term effect of nitric oxide)}

To distinguish between short term (1 hour) and long term (16 hours) effects of nitric oxide on viable cells, cell monolayers were given a one time dose of sodium nitroprusside, S-nitroso-N-acetylpenicillamine or ethanol 16 hours before assays were performed (long term effect, fig. 5a and b, left panels, 16 hours). Sodium nitroprusside, S-nitroso- $\mathrm{N}$-acetylpenicillamine and/or ethanol were added to the suspensions of untreated cells in complete media for one hour prior to the assays (fig. 5a and $b$, right panels, 1 hour) to monitor the short term effect of nitric oxide. Before performing the assays, cells
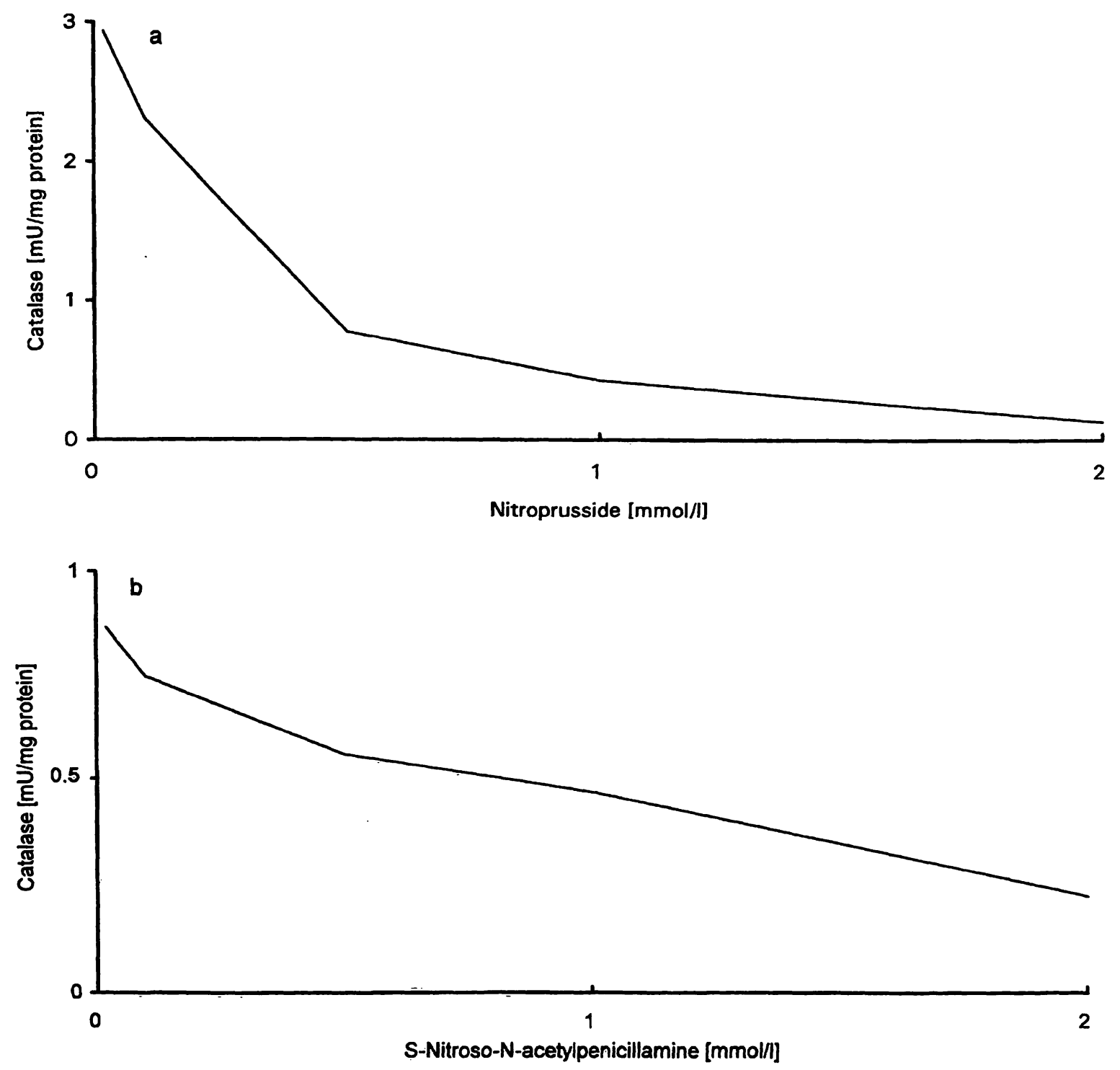

Fig. 4 Treatment 4, dose-response. Different concentrations of sodium nitroprusside (a) and $\mathrm{S}$-nitroso-N-acetylpenicillamine (b) were applied directly to the catalase assays. 
were washed twice with Hank's balanced salt solution to remove effectors. Addition of sodium nitroprusside or $\mathrm{S}$-nitroso- $\mathrm{N}$-acetylpenicillamine to the cell monolayer 16 hours prior to the assays does not alter the oxidation rate of lignoceric acid (fig. 5b, left panel, Nitroprusside 16 hours). Sodium nitroprusside, added to the cells for one hour (fig. 5b, right panel, Nitroprusside 1 hour), significantly enhances the activity of lignoceric acid oxidation $(p<0.05, n=5)$. Catalase activity is significantly decreased $(p<0.01, n=6)$ after overnight addition of sodium nitroprusside (fig. 5a left panel, Nitroprusside 16 hours) and increased after 1 hour of incubation with sodium nitroprusside (fig. 5a, right panel, Nitroprusside 1 hour). S-Nitroso-N-acetylpenicillamine does not influence the activity, probably because of its poor solubility or rate of release of nitric oxide in culture media (fig. 5a, SNAP 16 hours and SNAP 1 hour).

Neither sodium nitroprusside nor S-nitroso-N-acetylpenicillamine ( $2 \mathrm{mmol} / \mathrm{l})$, applied to cells either in culture or cell suspension, show the effect of direct application to the assays (fig. 3). This shows that direct application of nitric oxide produces different effects with respect to peroxisomal enzyme activities in total cells and under assay conditions.

\section{Conclusion}

Peroxisomal enzyme activities are regulated by nitric oxide. Under assay conditions the mechanism probably
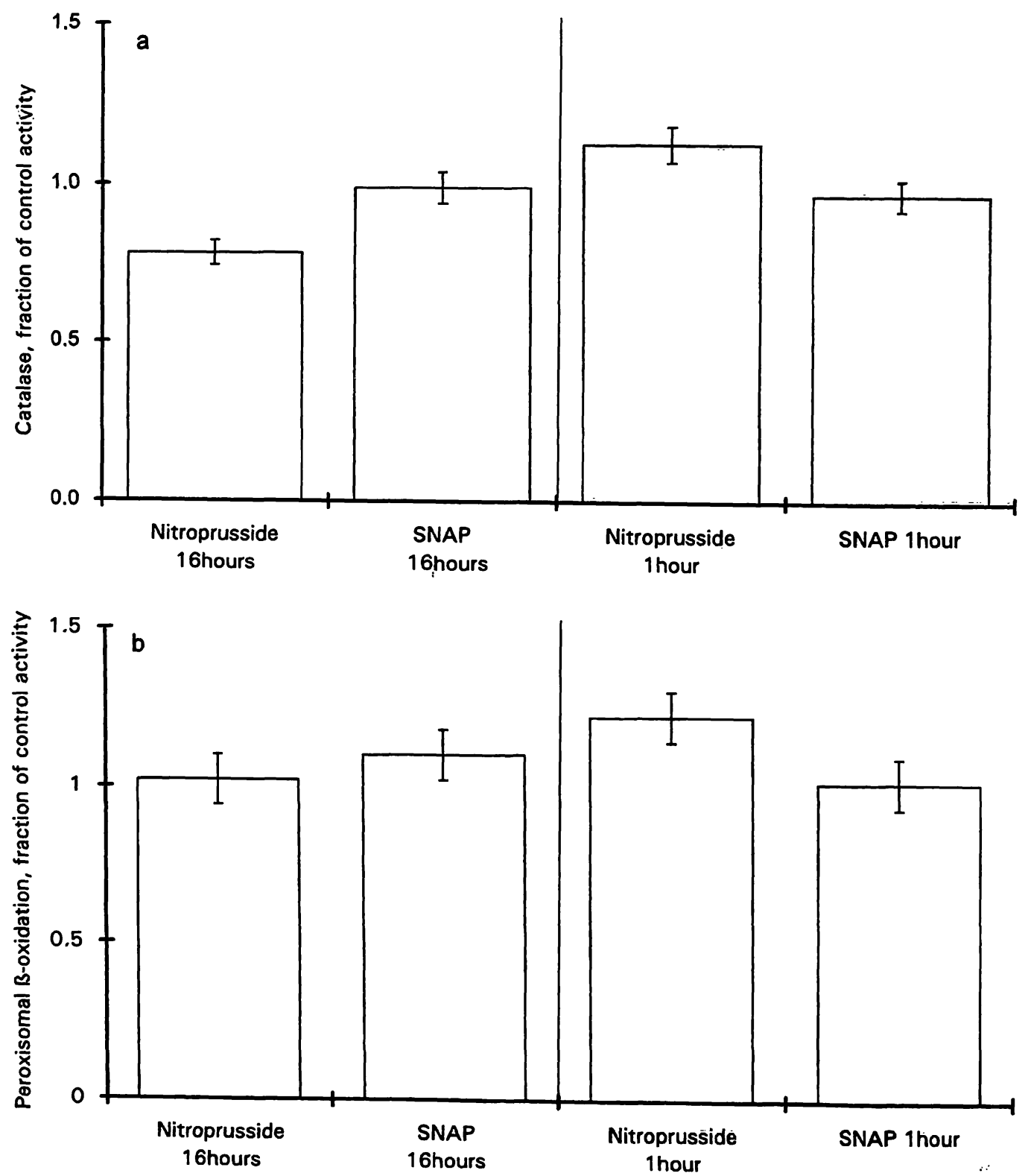

Fig. 5 Treatment 5: Short and long term effect of nitric oxide-donors.

Sodium nitroprusside $(2 \mathrm{mmol} / \mathrm{l})$ or S-nitroso-N-acetylpenicillamine (SNAP, $2 \mathrm{mmol} / \mathrm{l}$ ) were added to monolayers for 16 hours

( $16 \mathrm{~h}$, left panels) or cells suspended in complete media for 1 hour $(1 \mathrm{~h}$, right panels). The activities of catalase (a) or the peroxisomal $\beta$-oxidation (b) were determined. Control $=1$. 
involves a decrease in catalase activity mediated by the free radical $-\mathrm{N}=\mathrm{O}$ or its reaction product with superoxide, peroxynitrite, causing oxidative damage $(29,30)$. The decrease in catalase activity is followed by higher levels of hydrogen peroxide within the peroxisomes (13). Hydrogen peroxide is known to inhibit the peroxisomal $\beta$-oxidation (42). Under tissue culture conditions increased nitric oxide synthesis also decreases catalase activity but enhances the activity of the peroxisomal $\beta$-oxidation. This effect can not be

\section{References}

1. Rhodin J. Correlation of ultrastructural organisation and function in normal and experimentally changed proximal convoluted tubule cells of the mouse kidney [doctoral thesis]. Stockholm: Aktiebolaget Godwil, 1954.

2. Hruban Z, Vigil EL, Slesers A, Hopkins E. Microbodies: constituent organelles of animal cells. Lab Invest 1972; 27:18491.

3. Van den Bosch H, Schutgens RBH, Wanders RJA, Tager JM. Biochemistry of peroxisomes. Annu Rev Biochem 1992; 61:157-97.

4. De Duve C, Baudhuin P. Peroxisomes (microbodies and related particles). Physiol Rev 1966; 46:323-57.

5. Brown FR, Voigt R, Singh AK, Singh I. Peroxisomal disorders - neurodevelopmental and biochemical aspects. Am J Dis Child 1993; 147:617-26.

6. Tolbert NE. Metabolic pathways in peroxisomes and glyoxysomes. Annu Rev Biochem 1981; 50:133-57.

7. Lazarow PB, de Duve C. A fatty acyl-CoA oxidizing system in rat liver peroxisomes; enhancement by clofibrate, a hypolipidemic drug. Proc Natl Acad Sci, USA 1976; 73:2043-6.

8. Singh I, Moser AE, Goldfischer SL, Moser HW. Lignoceric acid is oxidized in the peroxisome: implications for the Zellweger cerebro-hepato-renal syndrome and adrenoleukodystrophy. Proc Natl Acad Sci, UȘA 1984; 81:4203-7.

9. Hajra AK, Burkes CL, Jones CL. Subcellular localization of acyl-coenzyme A: dihydroxyacetone phosphate acyltransferase in rat liver peroxisomes (microbodies). J Biol Chem 1979; 254:10896-900.

10. Hajra AK, Bishop JE. Glycerolipid biosynthesis in peroxisomes via the acyl dihydroxyacetone phosphate pathway. Ann NY Acad Sci 1982; 386:170-82.

11. Freeman BA, Crapo JD. Biology of disease: free radicals and tissue injury. Lab Invest 1982; 47:412-26.

12. Gutteridge JMC. Biological origin of free radicals, and mechanisms of antioxidant protection. Chem Biol Interact 1994; 91:133-40.

13. Chance B, Sies $\mathrm{H}$, Boveris A. Hydroperoxide metabolism in mammalian organs. Physiol Rev 1979; 59:527-605.

14. Kremser K, Kremser-Jezik M, Singh I. Effect of hypoxia-reoxygenation on peroxisomal functions in cultured human skin fibroblasts from control and Zellweger syndrome patients. Free Radical Res 1995; 22:39-46.

15. Gulati S, Singh AK, Irazu C, Orak JK, Rajagopalan PR, Fitts $\mathrm{CT}$, et al. Ischemia-reperfusion injury: biochemical alterations in peroxisomes of rat kidney. Arch Biochem Biophys 1992; 295:90-100.

16. Gulati S, Ainol L, Orak J, Singh AK, Singh I. Alterations of peroxisomal function in ischemia-reperfusion injury of rat kidney. Biochim Biophys Acta 1993; 1182:291-8.

17. Dhaunsi GS, Hanevold CD, Singh I. Impairment of peroxisomal beta-oxidation system by endotoxin treatment. Mol Cell Biochem 1994; 135:187-93. explained with higher levels of hydrogen peroxide, since reactive oxygen species inhibit both catalase (43, $44)$ and peroxisomal $\beta$-oxidation $(14-16,21)$, but demonstrates the action of nitric oxide as a second messenger on cellular level.

\section{Acknowledgements}

The authors thank Ms. Jan Ashcraft and Ms. Margarete KrenserJezik for their skillful technical assistance.
18. Gulati S, Dhaunsi GS, Singh AK, Singh I. Effect of ciprofibrate on peroxisomal antioxidant-enzyme system in rat liver [abstract]. Free Radical Biol Med 1993, 15:505.

19. Dhaunsi GS, Singh I, Orak JK, Singh AK. Antioxidant enzymes in ciprofibrate-induced oxidative stress. Carcinogenesis 1994; 15:1923-30.

20. Del Rio LA, Sandalio LM, Palma JM. A new cellular function for peroxisomes related to oxygen free radicals? Experientia 1990; 46:989-92.

21. Del Rio LA, Sandalio LM, Palma JM, Bueno P, Corpas FJ. Metabolism of oxygen radicals in peroxisomes and cellular implications. Free Radical Biol Med 1992; 13:557-80.

22. Moncada S. The L-arginine: nitric oxide pathway. Acta Physiol Scand 1992; 145:201-27.

23. Knowles RG, Moncada S. Nitric oxide synthases in mammals. Biochem J 1994; 298:249-58.

24. Schmidt HHHW, Lohmann SW, Walter U. The nitric oxide and cGMP signal transduction system: regulation and mechanism of action. Biochim Biophys Acta 1993; 1178:153-75.

25. Marletta MA. Nitric oxide synthase structure and mechanism. J Biol Chem 1993; 268:12231-4.

26. Lipton SA, Choi YB, Pan ZH, Lei SZZ, Chen HSV, Sucher $\mathrm{NJ}$, et al. A redox-based mechanism for the neuroprotective and neurodestructive effects of nitric oxide and related nitrosocompounds. Nature 1993; 364:626-32.

27. Moncada S. Nitric oxide gas: mediator, modulator, and pathophysiologic entity. J Lab Clin Med 1992; 120:187-91.

28. Schmidt HHHW. NO, CO and $\mathrm{OH}$ : endogenous soluble guanylyl cyclase-activating factors. FEBS Lett 1992; 307:102-7.

29. Beckman JS, Beckman TW, Chen J, Marshall PA, Freeman BA. Apparent hydroxyl radical production by peroxynitrite: implications for endothelial injury from nitric oxide and superoxide. Proc Natl Acad Sci, USA 1990; 87:1620-4.

30. Radi R, Beckman JS, Bush KM, Freeman BA. Peroxynitriteinduced membrane lipid peroxidation: the cytotoxic potential of superoxide and nitric oxide. Arch Biochem Biophys 1991; 288:481-7.

31. Madison DV. Pass the nitric oxide. Proc Natl Acad Sci, USA 1993; 90:4329-31.

32. Snyder SH. Janus faces of nitric oxide. Nature 1993; 364:577.

33. Firnhaber C, Murphy ME. Nitric oxide and superoxide in cultured cells - limited production and influence on DNA synthesis. Am J Physiol 1993; 265:R518-23.

34. Lancaster JR, Wernerfelmayer G, Wachter H. Coinduction of nitric oxide synthesis and intracellular nonheme iron-nitrosyl complexes in murine cytokine-treated fibroblasts. Free Radical Biol Med 1994; 16:869-70.

35. Shindo $T$, Ikeda $U$, Ohkawa $F$, Takahashi $M$, Funayama $H$, Nishinaga $M$, et al. Nitric oxide synthesis in rat cardiac myocytes and fibroblasts. Life Sci 1994; 55:1101-8. 
36. Bradford M. A rapid and sensitive method for the quantitation of microgram quantities of proteinn utilizing the principle of protein dye binding. Anal Biochem 1976; 72:248-54.

37. Wanders RJA, Kos M, Roest B, Meijer AJ, Schrakamp G, Heymans HS, et al. Activity of peroxisomal enzymes and intracellular distribution of catalase in Zellweger syndrome. Biochem Biophys Res Commun 1984; 123:1054-61.

38. Lazo O, Contreras M, Hashmi M, Stanley W, Irazu C, Singh I. Peroxisomal lignocernyl-CoA ligase deficiency in childhood adrenoleukodystrophy and adrenomyeloneuropathy. Proc Natl Acad Sci, USA 1988; 85:7647-51.

39. Singh I, Lazo O, Contreras M, Stanley W, Hashimoto T. Rhizomelic chondrodysplasia punctata: biochemical studies of peroxisomes isolated from cultured skin fibroblasts. Arch Biochem Biophys 1991; 286:277-83.

40. Singh I, Lazo O, Kalipada P, Singh AK. Phytanic acid alphaoxidation in human cultured skin fibroblasts. Biochim Biophys Acta 1992; 1180:221-4.
41. Ioannidis I, Degroot $\mathrm{H}$. Cytotoxicity of nitric oxide in Fu 5 rat hepatoma cells - evidence for co-operative action with hydrogen peroxide. Biochem J 1993; 296:341-5.

42. Hashimoto $F$, Hayashi $H$. Significance of catalase in peroxisomal fatty acyl-CoA beta-oxidation. Biochim Biophys Acta 1987; 921:142-50.

43. Lee SS, Ye JH, Jones DP, McCormick DB. Correlation of $\mathrm{H}_{2} \mathrm{O}_{2}$ production and liver catalase during riboflavin deficiency and repletion in mammals. Biochem Biophys Res Commun 1983; 117:788-93.

44. Kono Y, Fridovich I. Superoxide radical inhibits catalase. J Biol Chem 1982; 257:5751-4.

Karl Kremser, Ph. D.

Institut für Medizinische Chemie

der Universität Wien

Währingerstrasse 10

A-1090 Wien

Austria 